\title{
Synthesis, In Vivo Anti-Inflammatory Activity, and Molecular Docking Studies of New Isatin Derivatives
}

\author{
Ravi Jarapula, ${ }^{1}$ Kiran Gangarapu, ${ }^{2}$ Sarangapani Manda, ${ }^{1}$ and Sriram Rekulapally ${ }^{1}$ \\ ${ }^{1}$ Department of Pharmaceutical Chemistry, University College of Pharmaceutical Sciences, Kakatiya University, \\ Telangana 506009, India \\ ${ }^{2}$ Department of Pharmaceutical Chemistry, Chaitanya Institute of Pharmaceutical Sciences, Rampur, Warangal, \\ Telangana 506147, India \\ Correspondence should be addressed to Sarangapani Manda; panimanda@gmail.com
}

Received 9 October 2015; Revised 10 December 2015; Accepted 17 December 2015

Academic Editor: Hussein El-Subbagh

Copyright (C) 2016 Ravi Jarapula et al. This is an open access article distributed under the Creative Commons Attribution License, which permits unrestricted use, distribution, and reproduction in any medium, provided the original work is properly cited.

\begin{abstract}
A novel synthesis of 2-hydroxy- $\mathrm{N}^{\prime}$-(2-oxoindolin-3-ylidene) benzohydrazide derivatives was synthesized by the condensation of 2-hydroxybenzohydrazide with substituted isatins. The synthesized compounds were characterized by FT-IR, ${ }^{1} \mathrm{H}-\mathrm{NMR}$, and mass spectral data. Further, the compounds were screened for in vivo anti-inflammatory activity by carrageenan induced paw edema method. The tested compounds have shown mild-to-moderate anti-inflammatory activity. The compounds VIIc and VIId exhibited $65 \%$ and $63 \%$ of paw edema reduction, respectively. The molecular docking studies were also carried out into the active site of COX1 and COX-2 enzymes (PDB ID: 3N8Y, 3LN1, resp.) using VLife MDS 4.3. The compounds VIIc, VIId, and VIIf exhibited good docking scores of $-57.27,-62.02$, and -58.18 onto the active site of COX-2 and least dock scores of $-8.03,-9.17$, and -8.94 on COX-1 enzymes and were comparable with standard COX-2 inhibitor celecoxib. A significant correlation was observed between the in silico and the in vivo studies. The anti-inflammatory and docking results highlight the fact that the synthesized compounds VIIc, VIId, and VIIf could be considered as possible hit as therapeutic agents.
\end{abstract}

\section{Introduction}

Cyclooxygenases (COX) or prostaglandin endoperoxide synthases are the key enzymes in the synthesis of prostaglandins, the main mediators of inflammation, pain, and increased body temperature (hyperpyrexia). The body produces two main isoforms of COX proteins, that is, cyclooxygenases1 (COX-1) and cyclooxygenases-2 (COX-2). The COX-1 is responsible for formation of important biological mediators such as prostanoids, including prostaglandins, prostacyclin, and thromboxane, and involved in pain causing, blood clotting, and protecting the stomach [1], whereas COX-2 is involved in the pain by inflammation and plays a major role in prostaglandin biosynthesis in inflammatory cells and central nervous system [2]. When COX-1 is inhibited, inflammation is reduced, but the protection of the lining of the stomach is also lost. This can cause stomach upset as well as ulceration and bleeding from the stomach and even the intestines.
Whereas COX-2 is usually specific to inflamed tissue, there is much less gastric irritation associated with COX-2 inhibition together with the decreased risk of peptic ulceration [3]. Therefore, selective COX-2 inhibitors such as celecoxib and rofecoxib had been developed for ease of inflammation associated with COX [4]. The use of coxib drugs such as rofecoxib $\left(\right.$ Vioxx $\left.^{\mathrm{W}}\right)$ and valdecoxib $\left(\right.$ Bextra $\left.^{\mathrm{W}}\right)$ was withdrawn from the market in 2004 and 2005, respectively, because of increased risk of heart attacks and strokes with long-term use [5]. At present, celecoxib (Celebrex ${ }^{\mathrm{W}}$ ) is the only COX-2 inhibitor available in the United States. Hence, there is a need for COX-2 inhibitor with no adverse effects.

The isatin (indole-2,3-dione) pharmacophore has attracted and still attracts much attention from medicinal chemists because of great importance in their biological as well as synthetic approach of medicinal chemistry. The various derivatives of isatin are known to possess a range of 
biological properties including anticancer [6], anticonvulsant [7], antidepressants [8], antimicrobial [9], antiviral [10], anxiolytics activities [11], molecular docking studies of isatin derivatives as EGFR inhibitors [12], and antiinflammatory [13], and the potent anti-inflammatory effect of indomethacin, etodolac, and tenidap encouraged us to further explore the pharmacological properties of the indole nucleus.

It has been reported that the nature of substituents at the 2- or 3-position of the indole nucleus plays an important role in modulating their anti-inflammatory properties [1418]. Amide-containing compounds have been shown to possess a wide range of biological activities, including antiinflammatory properties. Interestingly, the replacement of the carboxylic groups by amide groups in NSAID drugs indomethacin, meclofenamic acid, and ketoprofen conferred the compounds greater selectivity for COX-2 over the COX-1 enzyme [19].

Literature survey reveals that 4-hydroxybenzohydrazide ring is important for antimycobacterial activity [20]. In addition, many thiazoline derivatives exhibit a wide variety of biological activities such as antimicrobial [21], antiinflammatory [22], antihistaminic [23], antihypertensive [24], hypnotic [25], and anticonvulsant [26].

Keeping in view of biological importance of the two molecular moieties, namely, isatins and 2-hydroxybenzohydrazide, to study the condensation of isatins with 2-hydroxybenzohydrazide (II) has been felt worthwhile as depicted in Scheme 2. The synthesized compounds were screened for in vivo anti-inflammatory activity and molecular docking studies. These results were supported to design novel specific inhibitors of COX-2 by the comparative modelling of COX1 and COX-2 enzymes with the available pharmacophore. We hope that these molecules may be further explored as powerful and novel nonulcerogenic anti-inflammatory with selective inhibition of COX-2.

\section{Materials and Methods}

2.1. General. All the chemicals used were of analytical grade and obtained from Himedia and SD Fine Chemicals. The completion of the reaction, the purity of the compounds checked by TLC using E-Merck $0.25 \mathrm{~mm}$ silica gel plates, and visualization were accomplished with UV light. Melting points were determined on Bio Technics India melting point apparatus and were uncorrected. ${ }^{1} \mathrm{H}$ NMR spectra were recorded on an Avance- $300 \mathrm{MHz}$ in $\mathrm{CDCl}_{3}$ solvent using TMS as an internal standard (chemical shifts in $\delta, \mathrm{ppm}$ ). The IR spectra were recorded on Rkin Elmer Spectrum BX1 spectrometer by using $\mathrm{KBr}$ disc. The mass spectra were recorded on a LC-MSD-Trap-SL.

2.2. Animals. The animals were procured from Mahaveer Enterprises, Hyderabad, India. Male adult albino Wister rats (150-350 g) were acclimatized for a period of 14 days prior to performing the experiments and maintained under standard husbandry conditions and had free access to food and water ad libitum. The animals were divided into different groups; each consists of six animals which were fasted overnight prior to the study. The protocol of the present study was reviewed and approved by the Institutional Animal Ethical Committee.

\section{Chemistry}

\subsection{Synthesis of Indole-2,3-diones (Isatins, III)}

3.1.1. Isonitrosoacetanilides (I1). In a 5 lit. RB flask, chloral hydrate $(0.54 \mathrm{~mol})$ and $1200 \mathrm{~mL}$ of water were placed. To this solution, crystallized sodium sulphate (1300 g) was then added followed by a solution of an appropriate aromatic amine (I) in $300 \mathrm{~mL}$ of water and concentrated hydrochloric acid $(0.52 \mathrm{~mol})$. Finally, a solution of hydroxylamine $\mathrm{HCl}$ $(1.58 \mathrm{~mol})$ in $500 \mathrm{~mL}$ of water was added. The contents of the flask were heated over a wire-gauge by a Mecker burner so that vigorous boiling begins in about 45 minutes. After 1 to 2 minutes of vigorous boiling the reaction was completed. During the heating period itself the crystals of isonitrosoacetanilides started separating out. On cooling under the current of water, the entire product was solidified. It was filtered under suction, air dried, and purified by recrystallization from suitable solvent(s).

3.1.2. Indole-2,3-diones (III). Sulphuric acid (600 g, d, 1.84, $326 \mathrm{~mL}$ ) were warmed at $50^{\circ} \mathrm{C}$ in a one liter RB flask fitted with an efficient mechanical stirrer and to this, finely powdered appropriate isonitrosoacetanilide (II, $0.46 \mathrm{~mol}$ ) was added at such a rate so as to maintain the temperature between $60^{\circ} \mathrm{C}$ and $70^{\circ} \mathrm{C}$ but not higher. External cooling was applied at this stage so that the reaction could be carried out more rapidly. After the addition of isonitroso compound was completed the temperature of the solution was raised to $80^{\circ} \mathrm{C}$ and maintained at that temperature for 10 minutes, to complete the reaction. Then the reaction mixture was cooled to room temperature and poured on crushed ice $(2.5 \mathrm{~kg})$ while stirring. After standing for about half-an-hour, the product separated was filtered, washed several times with small portions of cold water, and dried. Purification of the compound was affected by the recrystallization from methanol [27].

3.2. Preparation of 2-Hydroxybenzohydrazide (VI). In a $500 \mathrm{~mL}$ of RB flask, $10 \mathrm{~g}$ of methyl salicylate (V) and $50 \mathrm{~mL}$ of distilled alcohol were placed and the reaction mixture was shaken for 5 minutes. To this add $20 \mathrm{~mL}$ of hydrazine hydrate (99\%) and the contents of the flask were refluxed for 3 hours, the completion of the reaction monitored by TLC. The resultant white crystalline solid was filtered and washed repeatedly, with small portions of cold alcohol. The product was dried and purified by recrystallization from methanol, yield $90 \%$, m.p. $251-254^{\circ} \mathrm{C}$ [28].

3.3. Synthesis of 2-Hydroxy-N'-(2-oxoindolin-3-ylidene)benzohydrazide (VII). A mixture of an appropriate indole-2,3dione $(0.01 \mathrm{~mol})$ and 2-hydroxybenzohydrazide $(0.01 \mathrm{~mol})$ was taken into methanol $(50 \mathrm{~mL})$ in presence of glacial acetic acid which was heated under reflux on water bath for 6-7 hours. The coloured compounds were thus obtained upon cooling, were filtered, were washed with small portions 
of cold methanol, and were dried. They were purified by recrystallization from alcohol.

\section{Spectral Data of the Synthesized Compounds}

(1) 2-Hydroxybenzohydrazide (VI). IR (KBr) $\mathrm{cm}^{-1}: 3320.78$ (NH), 1623 (C=O), 1479 (C-N), 830-500 (Ar); MS: m/z 152 $\left(\mathrm{M}^{+}\right)$.

(2) 2-Hydroxy- $N^{\prime}$-(2-oxoindolin-3-ylidene)benzohydrazide (VIIa). IR (KBr) cm $\mathrm{cm}^{-1}$ : $3169(\mathrm{NH}), 1735.97(\mathrm{C}=\mathrm{O}), 1663.97$ $(\mathrm{C}=\mathrm{O}), 1527.60(\mathrm{C}=\mathrm{N}) ;{ }^{1} \mathrm{H}$ NMR $\left(300 \mathrm{MHz}, \mathrm{DMSO}-\mathrm{CDCl}_{3}\right)$ : $\delta$ [ppm], 6.85-7.85 (m, 8H, Ar-H), 10.9 (s, $1 \mathrm{H}, \mathrm{CONH}), 11.6$ (s, $1 \mathrm{H}$, indole $\mathrm{NH}$ ), 14.4 (s, $1 \mathrm{H}, \mathrm{OH}$ phenolic); MS: $m / z 281$ $\left(\mathrm{M}^{+}\right)$.

(3) 2-Hydroxy-N' -(5-methyl-2-oxoindolin-3-ylidene)benzohydrazide (VIIb). IR (KBr) cm $\mathrm{cm}^{-1}: 3170(\mathrm{NH}), 3060(\mathrm{C}-\mathrm{H})$, $1719(\mathrm{C}=\mathrm{O}), 1664(\mathrm{C}=\mathrm{O}), 1527(\mathrm{C}=\mathrm{N}) .{ }^{1} \mathrm{H}-\mathrm{NMR}\left(\mathrm{DMSO}-d_{6}\right)$ : $\delta[\mathrm{ppm}], 2.6\left(\mathrm{~s}, 3 \mathrm{H}, \mathrm{CH}_{3}\right), 7.2(\mathrm{~s}, 1 \mathrm{H}, \mathrm{Ar}-\mathrm{H}), 7.4(\mathrm{~d}, 1 \mathrm{H}, \mathrm{Ar}-\mathrm{H})$ $7.6(\mathrm{t}, 2 \mathrm{H}, \mathrm{Ar}-\mathrm{H}), 7.7$ (d, 1H, Ar-H), 7.92 (d, 2H, Ar-H), 11.6 (s, $1 \mathrm{H}$, indole $\mathrm{NH}), 11(\mathrm{~s}, 1 \mathrm{H}, \mathrm{CONH}), 14.1(\mathrm{~s}, 1 \mathrm{H}, \mathrm{OH}$ phenolic). MS: $m / z 295\left(\mathrm{M}^{+}\right)$.

(4) 2-Hydroxy- $N^{\prime}$-(5-chloro-2-oxoindolin-3-ylidene)benzohydrazide (VIIc). IR (KBr) cm ${ }^{-1}: 3170.58(\mathrm{NH}), 1724.26$ $(\mathrm{C}=\mathrm{O}), 1675.74(\mathrm{C}=\mathrm{O}), 1528.08(\mathrm{C}=\mathrm{N}), 768(\mathrm{C}-\mathrm{Cl}) .{ }^{1} \mathrm{H}-\mathrm{NMR}$ (DMSO- $\left.d_{6}\right): \delta[\mathrm{ppm}]: 6.92(\mathrm{~s}, 1 \mathrm{H}, \mathrm{Ar}-\mathrm{H}), 7.21(\mathrm{~d}, 1 \mathrm{H}, \mathrm{Ar}-\mathrm{H})$, 7.52 (t, 2H, Ar-H), 7.81 (d, 1H, Ar-H), 7.94 (d, 2H, Ar-H), 10.4 $(\mathrm{s}, 1 \mathrm{H}, \mathrm{CONH}), 12.6(\mathrm{~s}, 1 \mathrm{H}$, indole $), 14.6(\mathrm{~s}, 1 \mathrm{H}, \mathrm{OH}$ phenolic $)$. MS: $m / z 315\left(\mathrm{M}^{+}\right), 317\left(\mathrm{M}^{+2}\right)$.

(5) 2-Hydroxy-N'-(5-bromo-2-oxoindolin-3-ylidene)benzohydrazide (VIId). IR (KBr) cm ${ }^{-1}: 3236.95(\mathrm{NH}), 1676.20$ $(\mathrm{C}=\mathrm{O}), 1628.43(\mathrm{C}=\mathrm{O}), 1542.03(\mathrm{C}=\mathrm{N}) .{ }^{1} \mathrm{H}-\mathrm{NMR}$ (DMSO$\left.d_{6}\right): \delta[\mathrm{ppm}]: 7.02(\mathrm{~s}, 1 \mathrm{H}, \operatorname{Ar}-\mathrm{H}), 7.42(\mathrm{~d}, 1 \mathrm{H}, \operatorname{Ar}-\mathrm{H}), 7.62(\mathrm{t}$, $2 \mathrm{H}, \operatorname{Ar}-\mathrm{H}), 7.84$ (d, 1H, Ar-H), 7.89 (d, 2H, Ar-H), 11.4 (s, 1H, $\mathrm{CONH}), 12.2(\mathrm{~s}, 1 \mathrm{H}$, indole $\mathrm{NH}), 14.1(\mathrm{~s}, 1 \mathrm{H}, \mathrm{OH}$ phenolic). MS: $m / z 360\left(\mathrm{M}^{+}\right)$.

(6) 3-(2-(2-Hydroxybenzoyl)hydrazono)-2-oxoindoline-5-carboxylic Acid (VIIe). IR (KBr) cm ${ }^{-1}: 3289.98(\mathrm{NH}), 1702.00$ $(\mathrm{C}=\mathrm{O}), 1676.94(\mathrm{C}=\mathrm{O}), 1529.67(\mathrm{C}=\mathrm{N}) .{ }^{1} \mathrm{H}-\mathrm{NMR}$ (DMSO$\left.d_{6}\right)$ : $7.12(\mathrm{~s}, 1 \mathrm{H}, \mathrm{Ar}-\mathrm{H}), 7.32(\mathrm{~d}, 1 \mathrm{H}, \mathrm{Ar}-\mathrm{H}), 7.42(\mathrm{t}, 2 \mathrm{H}, \mathrm{ArH})$, 7.91 (d, 1H, ArH), 7.94 (d, 2H, ArH), 10.1 (s, 1H, CONH), 12.6 (s, $1 \mathrm{H}$, indole $\mathrm{NH}), 14.0(\mathrm{~s}, 1 \mathrm{H}, \mathrm{OH}$ phenolic), $14.8(\mathrm{~s}, 1 \mathrm{H}$, carboxylic). MS: $m / z 326\left(\mathrm{M}^{+1}\right)$.

(7) 2-Hydroxy-N'-(1-methyl-2-oxoindolin-3-ylidene)benzohydrazide (VIIf). IR ( $\mathrm{KBr}) \mathrm{cm}^{-1}$ : $3160(\mathrm{NH}), 3122(\mathrm{C}-\mathrm{H}), 1731.90$ $(\mathrm{C}=\mathrm{O}), 1665.9(\mathrm{C}=\mathrm{O}), 1542.60(\mathrm{C}=\mathrm{N}) .{ }^{1} \mathrm{H}-\mathrm{NMR}\left(\mathrm{DMSO}-d_{6}\right)$ : $\delta[\mathrm{ppm}], 3.8\left(\mathrm{~s}, 3 \mathrm{H}, \mathrm{CH}_{3}\right), 6.95-7.82(\mathrm{~m}, 8 \mathrm{H}, \mathrm{Ar}-\mathrm{H}), 11.9(\mathrm{~s}, 1 \mathrm{H}$, CONH), 13.8 (s, $1 \mathrm{H}, \mathrm{OH}$ phenolic). MS: $m / z 296\left(\mathrm{M}^{+1}\right)$.

(8) 2-Hydroxy-N'-(1-acetyl-2-oxoindolin-3-ylidene)benzohydrazide (VIIg). IR (KBr) cm $\mathrm{cm}^{-1}: 3260(\mathrm{NH}), 3068(\mathrm{C}-\mathrm{H})$, $1791.90(\mathrm{C}=\mathrm{O}), 1685.47(\mathrm{C}=\mathrm{O}), 1542.60(\mathrm{C}=\mathrm{N}) .{ }^{1} \mathrm{H}$ NMR $\left(\mathrm{DMSO}-d_{6}\right): \delta[\mathrm{ppm}], 4.7\left(\mathrm{~s}, 3 \mathrm{H}, \mathrm{CH}_{3}\right), 6.82-7.80(\mathrm{~m}, 8 \mathrm{H}, \mathrm{Ar}-$ $\mathrm{H}), 11.5$ (s, 1H, CONH), 13.4 (s, $1 \mathrm{H}, \mathrm{OH}$ phenolic). MS: $\mathrm{m} / z$ $323\left(\mathrm{M}^{+}\right)$.
(9) 3-(2-(2-Hydroxybenzoyl)hydrazono)-2-oxoindoline-7-carboxylic Acid (VIIh). IR (KBr) cm $\mathrm{cm}^{-1}: 3219.98(\mathrm{NH}), 1722$ $(\mathrm{C}=\mathrm{O}), 1677.94(\mathrm{C}=\mathrm{O}), 15249.67(\mathrm{C}=\mathrm{N}){ }^{1}{ }^{1} \mathrm{H}$ NMR $(300 \mathrm{MHz}$, DMSO-CDCl 3 ): 7.02 (d, $1 \mathrm{H}, \mathrm{Ar}-\mathrm{H}), 7.22(\mathrm{~d}, 1 \mathrm{H}, \mathrm{Ar}-\mathrm{H}) 7.4(\mathrm{t}$, $2 \mathrm{H}, \mathrm{Ar}-\mathrm{H}), 7.87$ (t, $1 \mathrm{H}, \mathrm{ArH}), 7.9$ (d, 2H, ArH), 11.1 (s, $1 \mathrm{H}$, $\mathrm{CONH}), 12.0$ (s, 1H, indole $\mathrm{NH}), 14.2(\mathrm{~s}, 1 \mathrm{H}, \mathrm{OH}$ phenolic), 14.5 (s, $1 \mathrm{H}$, carboxylic); MS: $m / z 326\left(\mathrm{M}^{+1}\right)$.

(10) 2-Hydroxy- $\mathrm{N}^{\prime}$-(7-chloro-2-oxoindolin-3-ylidene)benzohydrazide (VIIi). IR (KBr) cm ${ }^{-1}: 3170.58(\mathrm{NH}), 1724.26$ $(\mathrm{C}=\mathrm{O}), 1675.74(\mathrm{C}=\mathrm{O}), 1528.08(\mathrm{C}=\mathrm{N}), 762(\mathrm{C}-\mathrm{Cl}) ;{ }^{1} \mathrm{H}-\mathrm{NMR}$ $\left(300 \mathrm{MHz}, \mathrm{DMSO}-\mathrm{CDCl}_{3}\right): \delta[\mathrm{ppm}]: 6.92(\mathrm{~d}, 1 \mathrm{H}, \mathrm{ArH}), 7.21$ (d, 1H, ArH), $7.52(\mathrm{t}, 2 \mathrm{H}, \mathrm{ArH}), 7.81(\mathrm{t}, 1 \mathrm{H}, \mathrm{ArH}), 7.94(\mathrm{~d}, 2 \mathrm{H}$, $\mathrm{ArH}), 10.4(\mathrm{~s}, 1 \mathrm{H}, \mathrm{CONH}), 12.6(\mathrm{~s}, 1 \mathrm{H}$, indole $\mathrm{NH}), 14.6(\mathrm{~s}, 1 \mathrm{H}$, $\mathrm{OH}$ phenolic); MS: $m / z 315\left(\mathrm{M}^{+}\right), 317\left(\mathrm{M}^{+2}\right)$.

(11) 2-Hydroxy- $N^{\prime}$-(7-bromo-2-oxoindolin-3-ylidene)benzohydrazide (VIIj). IR ( $\mathrm{KBr}) \mathrm{cm}^{-1}: 3236(\mathrm{NH}), 1674(\mathrm{C}=\mathrm{O}), 1628$ $(\mathrm{C}=\mathrm{O}), 1542,(\mathrm{C}=\mathrm{N}) ;{ }^{1} \mathrm{H}-\mathrm{NMR}(300 \mathrm{MHz}, \mathrm{DMSO}): \delta$ [ppm]: 7.20 (d, 1H, ArH), 7.40 (d, 1H, ArH), 7.60 (t, 2H, ArH), 7.84 (m, 1H, ArH), 7.89 (d, 2H, ArH), 11.4 (s, 1H, CONH), 12.8 (s, $1 \mathrm{H}$, indole $\mathrm{NH}), 14.12(\mathrm{~s}, 1 \mathrm{H}, \mathrm{OH}$ phenolic); MS: $m / z 345$ $\left(\mathrm{M}^{+1}\right)$.

\section{Biological Activities}

4.1. Acute Toxicity Studies. The study was conducted in accordance with OECD guidelines (Testing of Chemical Number 423). Healthy and adult male albino Swiss mice were used in this investigation. Animals were fasted for 24 hours and divided into groups of six animals. The test compounds, suspended in normal saline, were administered intraperitoneally, in doses of $10 \mathrm{mg}$ to $1000 \mathrm{mg}$ per $\mathrm{kg}$ (b.w.). The control groups of animals received only the vehicle (normal saline). The animals were observed for 48 hours from the time of administration of test compound, in a dose of $1000 \mathrm{mg} / \mathrm{kg}$ produce mortality $\left(\mathrm{LD}_{50}\right)$. Soon, tenth of the $\mathrm{LD}_{50}$, that is, $100 \mathrm{mg} / \mathrm{kg}\left(\mathrm{ED}_{50}\right)$, was selected as a dose for an anti-inflammatory.

4.2. Anti-Inflammatory Activity by Carrageenan Induced Rat Hind Paw Edema Method. In carrageenan model [29] albino rats of all groups were treated with subcutaneous injection of $0.1 \mathrm{~mL}$ of $1 \% \mathrm{w} / \mathrm{v}$ solution of carrageenan into the subplantar region of the right hind paw. The paw was marked with permanent marker at the planter region where the paw volume was to be measured. The indomethacin $10 \mathrm{mg} / \mathrm{kg}$ and test compounds $100 \mathrm{mg} / \mathrm{kg}$ were suspended in $0.3 \%$ sodium carboxymethyl cellulose. The test compounds and vehicle (control) were administered i.p. one hour after the injection of carrageenan in subplantar region of right paw. Mean normal paw volume was measured $30 \mathrm{~min}$ prior to carrageenan injection by using plethysmometer. Mean increase in the paw volume for control group (after carrageenan injection) and test group was measured at $1 \mathrm{hr}, 2 \mathrm{hr}, 3 \mathrm{hr}$, and $4 \mathrm{hr}$. Percent inhibition of inflammation after test/standard was calculated using the formula. The mean percent inhibition of indomethacin and tested compounds at $10 \mathrm{mg} \mathrm{kg}^{-1}$ concentrations was compared with control using repeated measures 


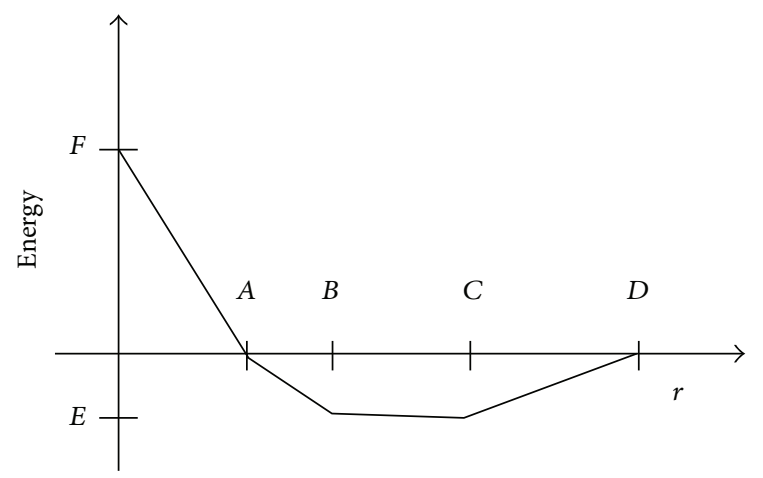

FIGURE 1: Graphical representation of functional of PLP scoring.

ANOVA with Dunnet's test. The data obtained is expressed as mean standard error of mean (SEM):

$\%$ Inhibition

$=\frac{\text { Mean edema of control group }- \text { Mean edema of test }}{\text { Mean edema of control group }}$

$\times 100$.

4.3. Molecular Docking. Docking simulation was done by GRIP batch docking method. GRIP docking employs the PLP scoring function in a novel way for fast and accurate capturing of ligand receptor interactions in the active site of proteins. For this purpose, VLife MDS 4.3 (http://www.vlifesciences.com) incorporates the Piecewise Linear Pairwise Potential (PLP) $[30,31]$ scoring function in GRIP docking method that includes interactions like hydrogen bonding, steric interactions, Vanderwaal's interactions, hydrophobic interactions, and electrostatic interactions. The PLP score is designed to enable flexible docking of ligands to perform a full conformational and positional search within a rigid binding site. The functional form of the ligand-protein interaction energy in PLP scoring function is shown in Figure 1. Parameters of the atomic pairwise ligand-protein potential are as follows: for steric interactions, $A=3.4, B=3.6$, $C=4.5, D=5.5, E=-0.4$, and $F=20.0$; for hydrogen bond interactions, $A=2.3, B=2.6, C=3.1, D=3.4, E=-2.0$, and $F=20.0$. The units of $A, B, C$, and $D$ are Angstrom; for $E$ and $F$ the units are arbitrary energy units [32].

The X-ray crystal structure of COX-1 and COX-2 (PDB codes: $3 \mathrm{~N} 8 \mathrm{Y}$ and $3 \mathrm{LN1}$, resp.) was downloaded from the protein data bank protein complexed with indomethacin and celecoxib, respectively. Water molecules were removed and hydrogen was added to the crystal structure of protein, refined by completing the incomplete residues and missing residues. The side chain hydrogen was then added to the crystal structure and its positions were optimized up to the rms gradient 1 by aggregating the other part of the receptor. The optimized receptor was then saved as mol2 file and used for docking simulation. The 2D structure of test compounds built and then converted into the 3D with<smiles>[R][M]c1ccc2c(c1)N([R2])C(=O)/C2=N/NC(=O)c1ccccc1O</smiles>

(VII)

SCHEME 1

the help of VLife MDS 4.3 software. The 3D structures were then energetically minimized up to the rms gradient of 0.01 using Merck Molecular Force Field (MMFF). All optimized ligands were docked into active site of COX proteins; the active site with the largest surface area is selected for docking. The parameters fixed for docking simulation were like this number of placements: 30 , rotation angle: $30^{\circ}$, exhaustive method, scoring function: PLP score. By rotation angle, the ligand gets rotated for different poses. By placements, the method will check all the 30 possible placements into the active site pocket and results in few best placements out of 30 . For each ligand, all the conformers with their best placements and their dock scores will be saved in output folder. The method also highlights the best placement of best conformer of one particular ligand which is having best (minimum) PLP score. After completion of the docking process, the minimum interaction energy between each ligand and COX proteins for the best ligand pose inside the receptor cavity was obtained as the PLP score. The PLP scores were compared with reference compounds.

\section{Results and Discussion}

Some of the new isatin derivatives were obtained by condensation of 2-hydroxybenzohydrazide with various isatins in presence of glacial acetic acid depicted in Scheme 2. Physical data of all synthesized compounds are shown in Table 1.

5.1. In Vivo Anti-Inflammatory Activity. All synthesized compounds were evaluated for in vivo anti-inflammatory activity at the dose of $100 \mathrm{mg} / \mathrm{kg}$ by carrageenan induced paw edema method. From the data it was revealed that all tested compounds significantly reduced carrageenan induced edema and the results were presented in Table 2. Among the tested compounds, VIIc $\left(\mathrm{R}_{1}=5-\mathrm{Cl}\right)$ and VIId $\left(\mathrm{R}_{1}=5-\mathrm{Br}\right)$ may be considered as potent anti-inflammatory agents and comparable with standard anti-inflammatory drug, indomethacin. Interestingly, derivatives with halo substitution at position C-5 and position C-7 of the isatin, compounds VIIc $\left(\mathrm{R}_{1}=\right.$ 5-Cl), VIId $\left(\mathrm{R}_{1}=5-\mathrm{Br}\right)$, VIIi $\left(\mathrm{R}_{1}=7-\mathrm{Cl}\right)$, and VIIj $\left(\mathrm{R}_{1}=7\right.$ $\mathrm{Br}$ ) exhibited substantial activity with $65 \%, 63 \%, 62 \%$, and $60 \%$ edema reduction. On the other hand, compounds with alkyl and acetyl substitution at position $\mathrm{N}-1$ of the isatin and compounds VIIf $\left(\mathrm{R}_{2}=\mathrm{CH}_{3}\right)$, VIIg $\left(\mathrm{R}_{2}=\mathrm{COCH}_{3}\right)$ are next in 
TABLE 1: Physical data of the newly synthesized compounds (VIIa-j). See Scheme 1.

\begin{tabular}{lccccccc}
\hline S. number & Compounds & $\mathrm{R}_{1}$ & $\mathrm{R}_{2}$ & Mol. F & Mol. wt. & M.P ( C) & \% yield \\
\hline 1 & VIIa & $\mathrm{H}$ & $\mathrm{H}$ & $\mathrm{C}_{15} \mathrm{H}_{11} \mathrm{~N}_{3} \mathrm{O}_{3}$ & 281 & $290-292$ \\
2 & VIIb & $5-\mathrm{CH}_{3}$ & $\mathrm{H}$ & $\mathrm{C}_{16} \mathrm{H}_{13} \mathrm{~N}_{3} \mathrm{O}_{3}$ & 295 & $285-287$ \\
3 & VIIc & $5-\mathrm{Cl}$ & $\mathrm{H}$ & $\mathrm{C}_{15} \mathrm{H}_{10} \mathrm{~N}_{3} \mathrm{O}_{3} \mathrm{Cl}$ & 315 & $294-296$ \\
4 & VIId & $5-\mathrm{Br}$ & $\mathrm{H}$ & $\mathrm{C}_{15} \mathrm{H}_{10} \mathrm{~N}_{3} \mathrm{O}_{3} \mathrm{Br}$ & 360 & $302-306$ \\
5 & VIIe & $5-\mathrm{COOH}$ & $\mathrm{H}$ & $\mathrm{C}_{16} \mathrm{H}_{11} \mathrm{~N}_{3} \mathrm{O}_{5}$ & 325 & $286-288$ \\
6 & VIIf & $\mathrm{H}$ & $\mathrm{N}-\mathrm{CH}_{3}$ & $\mathrm{C}_{16} \mathrm{H}_{13} \mathrm{~N}_{3} \mathrm{O}_{3}$ & 295 & $180-182$ \\
7 & VIIg & $\mathrm{H}$ & $\mathrm{N}-\mathrm{COCH}_{3}$ & $\mathrm{C}_{17} \mathrm{H}_{13} \mathrm{~N}_{3} \mathrm{O}_{4}$ & 323 & $152-155$ \\
8 & VIIh & $7-\mathrm{COOH}$ & $\mathrm{H}$ & $\mathrm{C}_{16} \mathrm{H}_{11} \mathrm{~N}_{3} \mathrm{O}_{5}$ & 325 & $287-289$ \\
9 & VIIi & $7-\mathrm{Cl}$ & $\mathrm{H}$ & $\mathrm{C}_{15} \mathrm{H}_{10} \mathrm{~N}_{3} \mathrm{O}_{3} \mathrm{Cl}$ & 315 & $295-297$ & 72 \\
10 & VIIj & $7-\mathrm{Br}$ & $\mathrm{H}$ & $\mathrm{C}_{15} \mathrm{H}_{10} \mathrm{~N}_{3} \mathrm{O}_{3} \mathrm{Br}$ & 360 & $300-302$ & 75 \\
\hline
\end{tabular}

TABLE 2: Showing the mean paw edema volume $(n=6)$ for newly synthesized compounds $(100 \mathrm{mg} / \mathrm{kg}$ bw) compared to standard drug indomethacin $(10 \mathrm{mg} / \mathrm{kg} \mathrm{bw})$.

\begin{tabular}{lccccc}
\hline S. number & Compound $(100 \mathrm{mg} / \mathrm{kg})$ & $1 \mathrm{hr}$ & $2 \mathrm{hr}$ & $3 \mathrm{hr}$ & $4 \mathrm{hr}$ \\
\hline 1 & Control & $0.75 \pm 0.05$ & $0.82 \pm 0.02$ & $0.94 \pm 0.09$ & $1.2 \pm 0.1$ \\
2 & VIIa & $0.65 \pm 0.01$ & $0.62 \pm 0.05$ & $0.58 \pm 0.03$ & $0.55 \pm 0.01(54)^{\mathrm{a}}$ \\
3 & VIIb & $0.64 \pm 0.08$ & $0.61 \pm 0.05$ & $0.60 \pm 0.01$ & $0.57 \pm 0.02(52)^{\mathrm{a}}$ \\
4 & VIIc & $0.55 \pm 0.02$ & $0.52 \pm 0.04$ & $0.48 \pm 0.07$ & $0.42 \pm 0.01(65)^{\mathrm{b}}$ \\
5 & VIId & $0.58 \pm 0.03$ & $0.56 \pm 0.09$ & $0.50 \pm 0.04$ & $0.44 \pm 0.08(63)^{\mathrm{b}}$ \\
6 & VIIe & $0.63 \pm 0.05$ & $0.61 \pm 0.02$ & $0.58 \pm 0.04$ & $0.54 \pm 0.01(55)^{\mathrm{b}}$ \\
7 & VIIf & $0.60 \pm 0.05$ & $0.57 \pm 0.08$ & $0.55 \pm 0.04$ & $0.51 \pm 0.03(57)^{\mathrm{b}}$ \\
8 & VIIg & $0.59 \pm 0.01$ & $0.56 \pm 0.07$ & $0.54 \pm 0.03$ & $0.50 \pm 0.05(58)^{\mathrm{b}}$ \\
9 & VIIh & $0.69 \pm 0.06$ & $0.67 \pm 0.02$ & $0.64 \pm 0.04$ & $0.61 \pm 0.01(49)^{\mathrm{a}}$ \\
10 & VIIi & $0.54 \pm 0.03$ & $0.52 \pm 0.01$ & $0.50 \pm 0.08$ & $0.45 \pm 0.06(62)^{\mathrm{b}}$ \\
11 & VIIj & $0.52 \pm 0.04$ & $0.50 \pm 0.08$ & $0.46 \pm 0.01$ & $0.48 \pm 0.02(60)^{\mathrm{b}}$ \\
12 & Indomethacin $(10 \mathrm{mg} / \mathrm{kg})$ & $0.51 \pm 0.02$ & $0.47 \pm 0.09$ & $0.42 \pm 0.04$ & $0.38 \pm 0.01(68)^{\mathrm{b}}$ \\
\hline
\end{tabular}

All the values are expressed as mean $\pm \mathrm{SD}(n=6) ;{ }^{\mathrm{a}} p<0.01,{ }^{\mathrm{b}} p<0.001$ versus control.

Results in parenthesis are \% of mean inhibition.

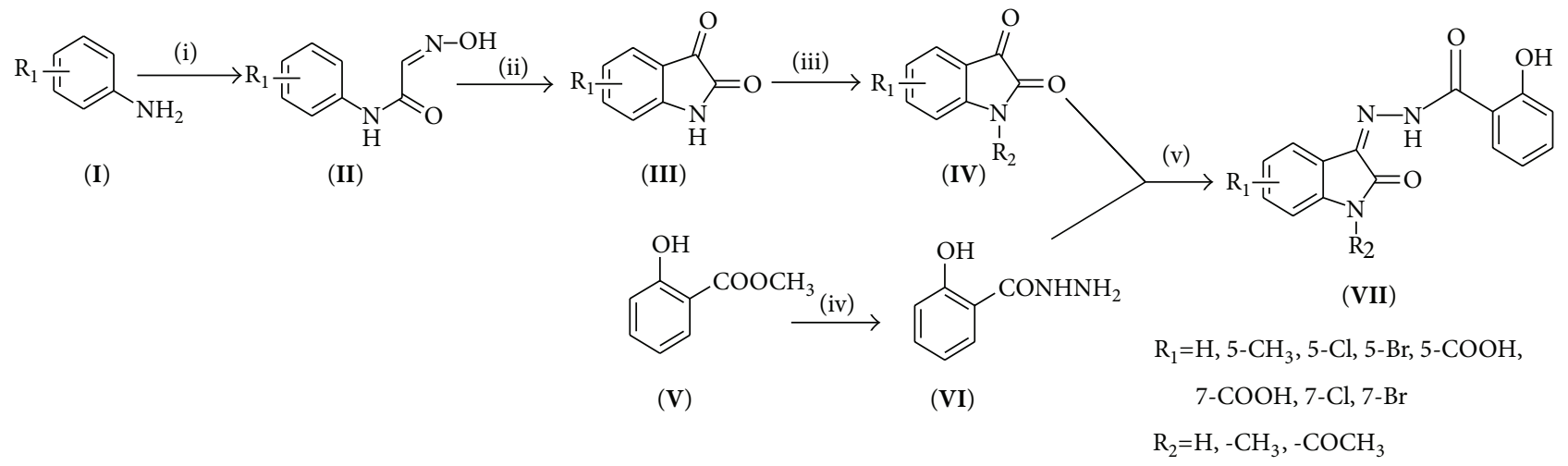

Reagents and reaction conditions
(i) $\mathrm{Cl}_{3} \mathrm{CH}(\mathrm{OH})_{2}, \mathrm{NH}_{2} \mathrm{OH} \mathrm{HCl}, \mathrm{Na}_{2} \mathrm{SO}_{4}$
(iv) $\mathrm{NH}_{2} \mathrm{NH}_{2} \mathrm{H}_{2} \mathrm{O}$, reflux, $80^{\circ} \mathrm{C}$
(ii) $\mathrm{Conc}_{2} \mathrm{SO}_{4}$
(v) gl. $\mathrm{CH}_{3} \mathrm{COOH}, \mathrm{CH}_{3} \mathrm{OH}$, reflux, $80^{\circ} \mathrm{C}$
(iii) $\mathrm{CH}_{3} \mathrm{Cl} / \mathrm{CH}_{3} \mathrm{COCl}$, DMF

Scheme 2: Schematic steps of 2-hydroxy- $\mathrm{N}^{1}$-(2-oxo-1,2-dihydro-3H-indol-3-ylidene)benzohydrazides. 
TABLE 3: Docking scores (PLP Scores) of comparative COX-1 and COX-2 enzymes.

\begin{tabular}{lccc}
\hline S. number & Compound & COX-1 & COX-2 \\
\hline 1 & VIIa & -10 & -65.52 \\
2 & VIIb & -8.72 & -48.97 \\
3 & VIIc & -8.03 & -57.27 \\
4 & VIId & -9.17 & -62.02 \\
5 & VIIe & -26.79 & -68.73 \\
6 & VIIf & -8.94 & -58.18 \\
7 & VIIg & -11 & -38.42 \\
8 & VIIh & -27.28 & -43.3 \\
9 & VIIi & -10.51 & -45.45 \\
10 & VIIj & -14.45 & -51.83 \\
11 & Indomethacin & -18.91 & -57.37 \\
12 & Celecoxib & -8.05 & -65.05 \\
\hline
\end{tabular}

the order of activity with $57.58 \%$ of edema reduction, whereas compounds VIIb $\left(\mathrm{R}_{1}=5-\mathrm{CH}_{3}\right)$, VIIa $\left(\mathrm{R}_{1}=\mathrm{R}_{2}=\mathrm{H}\right)$, VIIe, and VIIh (5\&7 COOH) exhibited 52\%, 54\%, 55\%, and 49\% of oedema reduction, respectively.

Compounds having substitution with electron withdrawing groups at C-5 and C-7 position of isatin moieties showed more anti-inflammatory activity whereas the other substitutions on various positions of isatin nucleus are next in the order of activity.

5.2. Molecular Docking Studies. The docking study was performed using the VLife MDS 4.3. All the ten 2-hydroxy$\mathrm{N}^{1}$-(2-oxo-1,2-dihydro-3H-indol-3-ylidene)benzohydrazide derivatives were docked into the active site of the enzymes COX-1 (PDB ID: 3N8Y) and COX-2 (PDB ID: 3LN1) which showed better docking scores than the reference compounds indomethacin and celecoxib and the results were presented in Table 3. Compounds VIIe and VIIh showed good docking scores $-68.73,-43.30$ with COX-2 enzyme even though they were not considered good anti-inflammatory agents because they are also having good dock scores -26.79 , -27.28 with COX-1 enzymes so these may be the causes of gastric irritation. The compounds VIIc, VIId, and VIIf are considered as good anti-inflammatory agents because of good binding scores $-57.27,-62.02$, and -58.18 into the active site of COX-2 and least dock scores $-8.03,-9.17$, and -8.94 on COX-1 enzymes. Compounds VIIc and VIId showed hydrogen bond interaction with Gln-275 and aromatic interaction with His-193 and compound VIIf showed hydrophobic interactions with Lys197, Asn217, His218, Gly221, Gly274, Glu222, and Gln275 with COX-2 enzyme whereas the reference compounds showed hydrophobic, van der waals interactions presented in Table 4, Figures 2-7.

\section{Conclusions}

We described herein the synthesis and characterization of a novel 2-hydroxy- $\mathrm{N}^{1}$-(2-oxo-1,2-dihydro-3H-indol-3-ylidene)benzohydrazide derivatives. All the synthesized

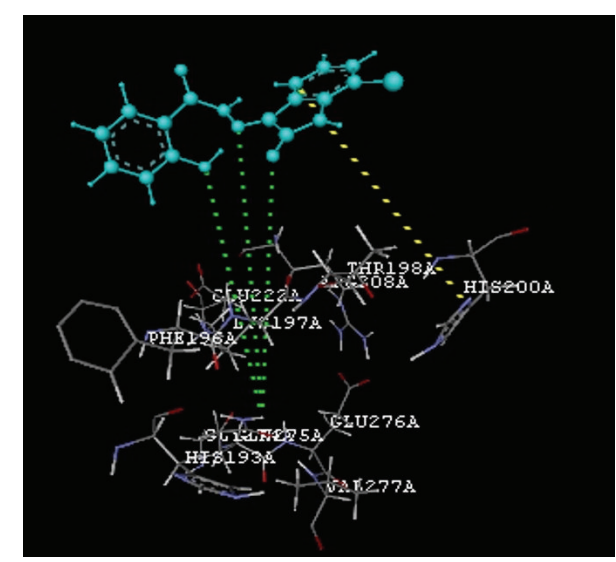

Figure 2: Compound VIIc $(\mathrm{R}=5-\mathrm{Cl})$ interactions.

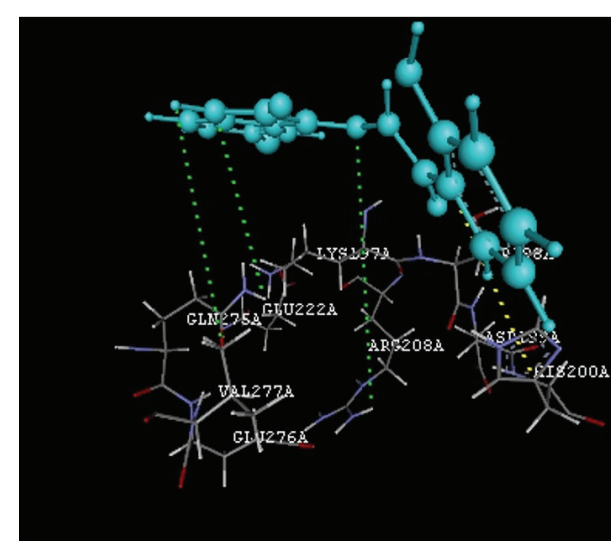

Figure 3: Compound VIId $(\mathrm{R}=5-\mathrm{Br})$ interactions.

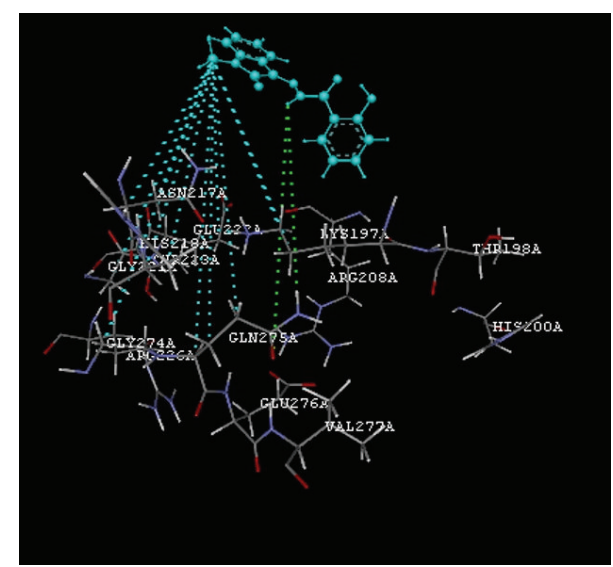

FIgURE 4: Compound VIIf $\left(\mathrm{R}=1-\mathrm{CH}_{3}\right)$ interactions.

compounds are subjected for the evaluation of in vivo anti-inflammatory activity at dose $100 \mathrm{mg} / \mathrm{kg}$. Among all, the compounds VIIc and VIId had good anti-inflammatory activity. Electron withdrawing groups seemed to be necessary factors in providing higher anti-inflammatory activity. 
TABLE 4: Binding interactions of cyclooxygenase enzyme.

\begin{tabular}{|c|c|c|c|c|c|c|c|c|}
\hline \multirow{2}{*}{ Compounds } & \multirow{2}{*}{ COX-1 } & \multirow{2}{*}{$\mathrm{COX}-2$} & \multicolumn{2}{|c|}{ Hydrogen bonds } & \multicolumn{2}{|c|}{ Aromatic bonds } & \multicolumn{2}{|c|}{ Hydrophobic bonds } \\
\hline & & & Dist. & Amino acid & Dist. & Amino acid & Dist. & Amino acid \\
\hline \multirow{2}{*}{ VIIc } & \multirow{2}{*}{-8.03} & \multirow{2}{*}{-57.27} & 2.073 & \multirow{2}{*}{$\mathrm{G} \ln 275$} & \multirow{2}{*}{4.702} & \multirow{2}{*}{ His193 } & & \\
\hline & & & 2.354 & & & & & \\
\hline \multirow{2}{*}{ VIId } & \multirow{2}{*}{-9.17} & \multirow{2}{*}{-62.02} & 2.073 & \multirow{2}{*}{$\mathrm{G} \ln 275$} & \multirow{2}{*}{5.211} & \multirow{2}{*}{ His193 } & & \\
\hline & & & 2.496 & & & & & \\
\hline \multirow{6}{*}{ VIIf } & \multirow{6}{*}{-8.94} & \multirow{6}{*}{-58.18} & 2.378 & \multirow{6}{*}{$\mathrm{G} \ln 275$} & \multirow{6}{*}{4.198} & \multirow{6}{*}{ His193 } & 4.473 & Lys197 \\
\hline & & & 2.51 & & & & 3.975 & Asn217 \\
\hline & & & & & & & 3.295 & His 218 \\
\hline & & & & & & & 4.336 & Gly221 \\
\hline & & & & & & & 4.675 & Glu222 \\
\hline & & & & & & & 3.663 & $\mathrm{G} \ln 275$ \\
\hline \multirow{3}{*}{ Indomethacin } & \multirow{3}{*}{-18.91} & \multirow{3}{*}{-57.37} & & & & & 4.865 & Lys201 \\
\hline & & & & & & & 4.396 & Ile260 \\
\hline & & & & & & & 3.802 & Val277 \\
\hline \multirow{6}{*}{ Celecoxib } & \multirow{6}{*}{-10.8} & \multirow{6}{*}{65.05} & & & & & 4.356 & Leu280 \\
\hline & & & & & & & 4.909 & Val277 \\
\hline & & & & & & & 4.953 & Glu276 \\
\hline & & & & & & & 4.986 & Arg208 \\
\hline & & & & & & & 4.589 & Lys197 \\
\hline & & & & & & & 2.305 & $\mathrm{G} \ln 275$ \\
\hline
\end{tabular}

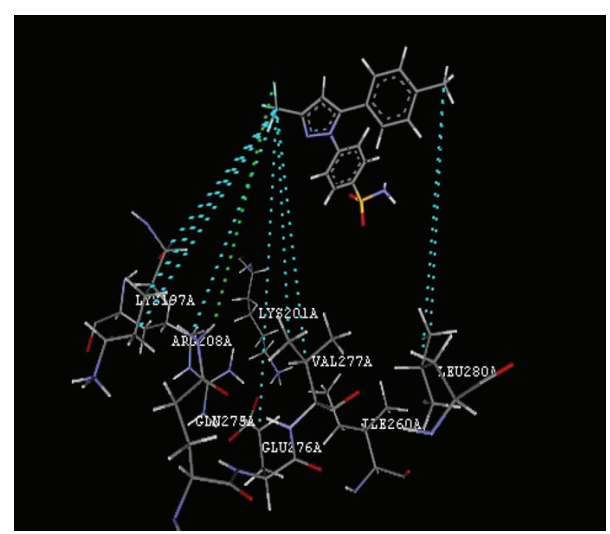

Figure 5: Celecoxib interactions.

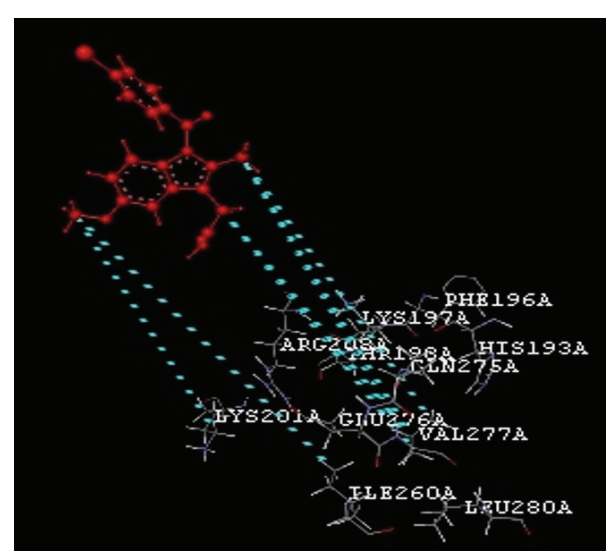

FIgURE 6: Indomethacin interactions.

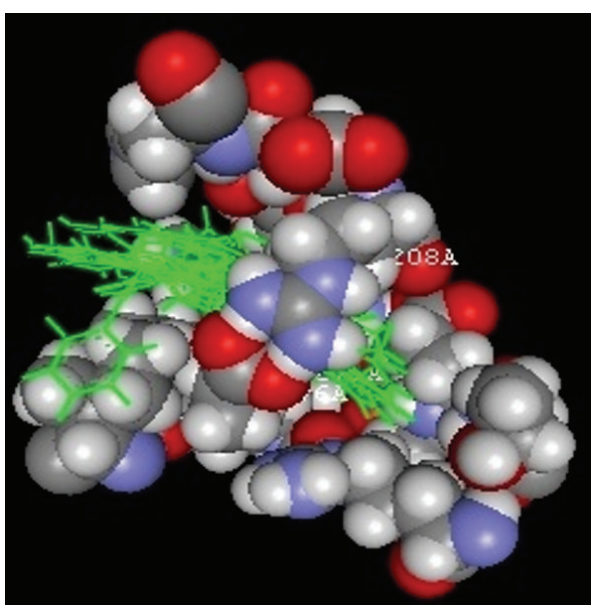

FIGURE 7: All docked complex.

The molecular docking studies further help in understanding the various interactions between the ligands and enzyme active sites in detail and thereby help to design novel potent inhibitor. The docking experiments were carried out for all the synthesized compounds on COX-1 and COX-2 enzymes and compared the docking score with reference compounds indomethacin and celecoxib. The compounds VIIc, VIId, and VIIf showed higher binding score, which are further attributed to the in vivo activity of these compounds. 


\section{Conflict of Interests}

The authors declare that there is no conflict of interests regarding the publication of this paper.

\section{Acknowledgments}

The authors are thankful to University College of Pharmaceutical sciences, Kakatiya University, for providing us all necessary facilities and also thankful to the University Grants Commission, New Delhi.

\section{References}

[1] D. J. Watson, S. E. Harper, P.-L. Zhao, H. Quan, J. A. Bolognese, and T. J. Simon, "Gastrointestinal tolerability of the selective cyclooxygenase-2 (COX-2) inhibitor rofecoxib compared with nonselective COX-1 and COX-2 inhibitors in osteoarthritis," Archives of Internal Medicine, vol. 160, no. 19, pp. 2998-3003, 2000.

[2] S. S. Chhajed, P. B. Hiwanj, V. A. Bastikar et al., "Structure based design and in-silico molecular docking analysis of some novel benzimidazoles," International Journal of ChemTech Research, vol. 2, no. 2, pp. 1135-1140, 2010.

[3] P. McGettigan and D. Henry, "Cardiovascular risk and inhibition of cyclooxygenase: a systematic review of the observational studies of selective and nonselective inhibitors of cyclooxygenase 2," The Journal of the American Medical Association, vol. 296, no. 13, pp. 1633-1644, 2006.

[4] C. J. Hawkey, “COX-2 inhibitors," The Lancet, vol. 353, no. 9149 , pp. 307-314, 1999.

[5] R. P. Mason, M. F. Walter, H. P. McNulty et al., "Rofecoxib increases susceptibility of human LDL and membrane lipids to oxidative damage: a mechanism of cardiotoxicity," Journal of Cardiovascular Pharmacology, vol. 47, no. 1, pp. S7-S14, 2006.

[6] K. Han, Y. Zhou, F. Liu et al., "Design, synthesis and in vitro cytotoxicity evaluation of 5-(2-carboxyethenyl)isatin derivatives as anticancer agents," Bioorganic \& Medicinal Chemistry Letters, vol. 24, no. 2, pp. 591-594, 2014.

[7] G. Saravanan, V. Alagarsamy, and P. Dineshkumar, "Anticonvulsant activity of novel 1-(morpholinomethyl)-3-substituted isatin derivatives," Bulletin of Faculty of Pharmacy, Cairo University, vol. 52, no. 1, pp. 115-124, 2014.

[8] C. Radhika, A. Venkatesham, and M. Sarangapani, "Synthesis and antidepressant activity of di substituted-5-aryl-1,2,4-triazoles," Medicinal Chemistry Research, vol. 21, no. 11, pp. 35093513, 2012.

[9] A. M. Naglah, H. M. Awad, M. A. Bhat, M. A. Al-Omar, and A. E. Amr, "Microwave-assisted synthesis and antimicrobial activity of some novel isatin schiff bases linked to nicotinic acid via certain amino acid bridge," Journal of Chemistry, vol. 2015, Article ID 364841, 8 pages, 2015.

[10] A. Jarrahpour, J. Sheikh, I. E. Mounsi, H. Juneja, and T. B. Hadda, "Computational evaluation and experimental in vitro antibacterial, antifungal and antiviral activity of bis-Schiff bases of isatin and its derivatives," Medicinal Chemistry Research, vol. 22, no. 3, pp. 1203-1211, 2013.

[11] B. V. Silva, "Isatin, a versatile molecule: studies in Brazil," Journal of the Brazilian Chemical Society, vol. 24, no. 5, pp. 707-720, 2013.
[12] S. Ganguly and B. Debnath, "Molecular docking studies and ADME prediction of novel isatin analogs with potent antiEGFR activity," Medicinal Chemistry, vol. 4, no. 8, pp. 558-568, 2014.

[13] R. Anisetti and M. S. Reddy, "Synthesis, antimicrobial, antiinflammatory and antioxidant activity of novel Spiro (imidazo[ $\left[4^{\prime}, 5^{\prime}: 4,5^{\prime}\right]$ benzo $[1,2$-e $][1,4]$ thiazepine)-9, $3^{\prime}$-indolines," Journal of Sulfur Chemistry, vol. 33, no. 3, pp. 363-372, 2012.

[14] D. Galanakis, A. P. Kourounakis, K. C. Tsiakitzis et al., "Synthesis and pharmacological evaluation of amide conjugates of NSAIDs with L-cysteine ethyl ester, combining potent antiinflammatory and antioxidant properties with significantly reduced gastrointestinal toxicity," Bioorganic \& Medicinal Chemistry Letters, vol. 14, no. 14, pp. 3639-3643, 2004.

[15] C. Papadopoulou, A. Geronikaki, and D. Hadjipavlou-Litina, "Synthesis and biological evaluation of new thiazolyl/benzothiazolyl-amides, derivatives of 4-phenyl-piperazine," II Farmaco, vol. 60, no. 11-12, pp. 969-973, 2005.

[16] T. Önkol, E. Banoglu, Y. Dündar, E. Küpeli, and M. F. Şahin, "Amide derivatives of [6-acyl-2-benzothiazolinon-3yl] acetic acids as potential analgesic and anti-inflammatory compounds," Medicinal Chemistry Research, vol. 19, no. 1, pp. 11-24, 2010.

[17] N. M. Raghavendra, A. Jyothsna, A. Venkateswara Rao, and C. V. S. Subrahmanyam, "Synthesis, pharmacological evaluation and docking studies of N-(benzo[d]thiazol-2-yl)-2-(piperazin1-yl)acetamide analogs as COX-2 inhibitors," Bioorganic and Medicinal Chemistry Letters, vol. 22, no. 2, pp. 820-823, 2012.

[18] T. Takahashi and M. Miyazawa, "N-Caffeoyl serotonin as selective COX-2 inhibitor," Bioorganic and Medicinal Chemistry Letters, vol. 22, no. 7, pp. 2494-2496, 2012.

[19] A. S. Kalgutkar, B. C. Crews, S. W. Rowlinson et al., "Biochemically based design of cyclooxygenase-2 (COX-2) inhibitors: facile conversion of nonsteroidal antiinflammatory drugs to potent and highly selective COX-2 inhibitors," Proceedings of the National Academy of Sciences of the United States of America, vol. 97, no. 2, pp. 925-930, 2000.

[20] S. D. Joshi, H. M. Vagdevi, V. P. Vaidya, and G. S. Gadaginamath, "Synthesis of new 4-pyrrol-1-yl benzoic acid hydrazide analogs and some derived oxadiazole, triazole and pyrrole ring systems: a novel class of potential antibacterial and antitubercular agents," European Journal of Medicinal Chemistry, vol. 43, no. 9, pp. 1989-1996, 2008.

[21] S. Rollas and M. Kiraz, "Synthesis and antimycobacterial activity of some coupling products from 4 -aminobenzoic acid hydrazones," European Journal of Medicinal Chemistry, vol. 34, no. 12, pp. 1093-1100, 1999.

[22] K. K. Vijaya Raj, B. Narayana, B. V. Ashalatha, N. Suchetha Kumari, and B. K. Sarojini, "Synthesis of some bioactive 2bromo-5-methoxy- $\mathrm{N}^{\prime}$-[4-(aryl)-1,3-thiazol-2-yl]benzohydrazide derivatives," European Journal of Medicinal Chemistry, vol. 42, no. 3, pp. 425-429, 2007.

[23] R. Maccari, R. Ottanà, and M. G. Vigorita, "In vitro advanced antimycobacterial screening of isoniazid-related hydrazones, hydrazides and cyanoboranes: part 14," Bioorganic and Medicinal Chemistry Letters, vol. 15, no. 10, pp. 2509-2513, 2005.

[24] X. Zhong, H.-L. Wei, W.-S. Liu, D.-Q. Wang, and X. Wang, "The crystal structures of copper(II), manganese(II), and nickel(II) complexes of a (Z)-2-hydroxy- $N^{\prime}$-(2-oxoindolin-3ylidene) benzohydrazide-potential antitumor agents," Bioorganic \& Medicinal Chemistry, vol. 17, no. 13, pp. 3774-3777, 2007. 
[25] V. A. Osyanin, P. P. Purygin, and Z. P. Belovsova, "Synthesis of 4-(1H-azol-1-ylmethyl)benzohydrazides and their acyclic and heterocyclic derivatives," Russian Journal of General Chemistry, vol. 75, no. 1, pp. 111-117, 2005.

[26] J. Patole, U. Sandbhor, S. Padhye, D. N. Deobagkar, C. E. Anson, and A. Powell, "Structural chemistry and in vitro antitubercular activity of acetylpyridine benzoyl hydrazone and its copper complex against Mycobacterium smegmatis," Bioorganic and Medicinal Chemistry Letters, vol. 13, no. 1, pp. 51-55, 2003.

[27] G. Henry and A. Blatt, Organic Synthesis Collective, John Wiley \& Sons, New York, NY, USA, 1964.

[28] R. P. Bhole, D. D. Borkar, K. P. Bhusari, and P. A. Patil, "Design and synthesis of p-hydroxybenzohydrazide derivatives for their antimycobacterial activity," Journal of the Korean Chemical Society, vol. 56, no. 2, pp. 236-245, 2012.

[29] C. A. Winter, E. A. Risely, and G. W. Nuss, "Carrageenan induced edema in hind paw of the rat as an assay for antiinflammatory," Proceedings of the Society for Experimental Biology and Medicine, vol. 111, no. 3, pp. 544-547, 1962.

[30] D. K. Gehlhaar, G. M. Verkhivker, P. A. Rejto et al., "Molecular recognition of the inhibitor AG-1343 by HIV-1 protease: conformationally flexible docking by evolutionary programming," Chemistry \& Biology, vol. 2, no. 5, pp. 317-324, 1995.

[31] G. M. Verkhivker, D. Bouzida, D. K. Gehlhaar et al., "Deciphering common failures in molecular docking of ligand-protein complexes," Journal of Computer-Aided Molecular Design, vol. 14, no. 8, pp. 731-751, 2000.

[32] S. Ajmani, S. Karanam, and S. A. Kulkarni, "Rationalizing protein-ligand interactions for PTP1B inhibitors using computational methods," Chemical Biology and Drug Design, vol. 74, no. 6, pp. 582-595, 2009. 

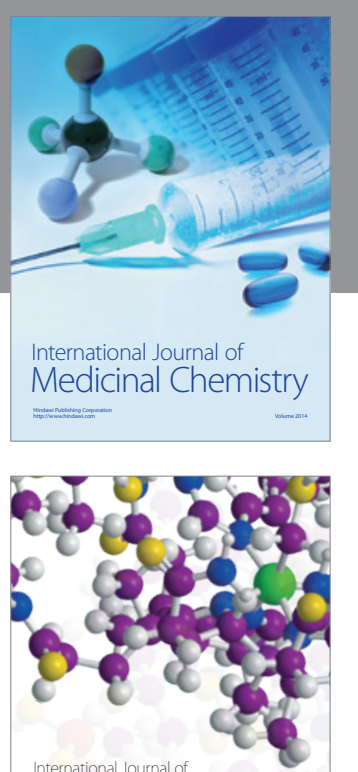

Carbohydrate Chemistry

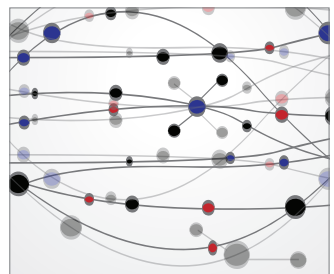

The Scientific World Journal
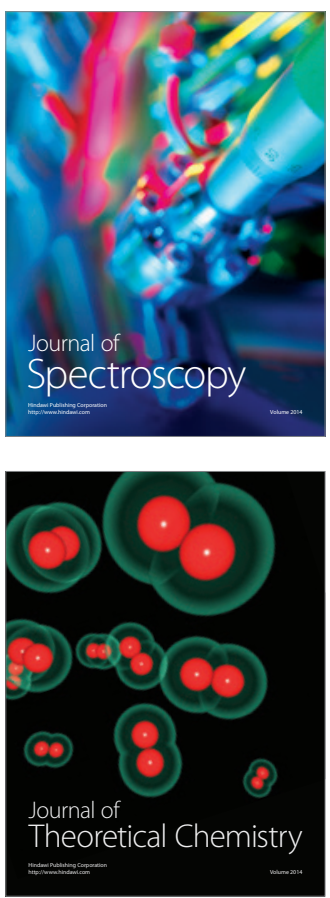
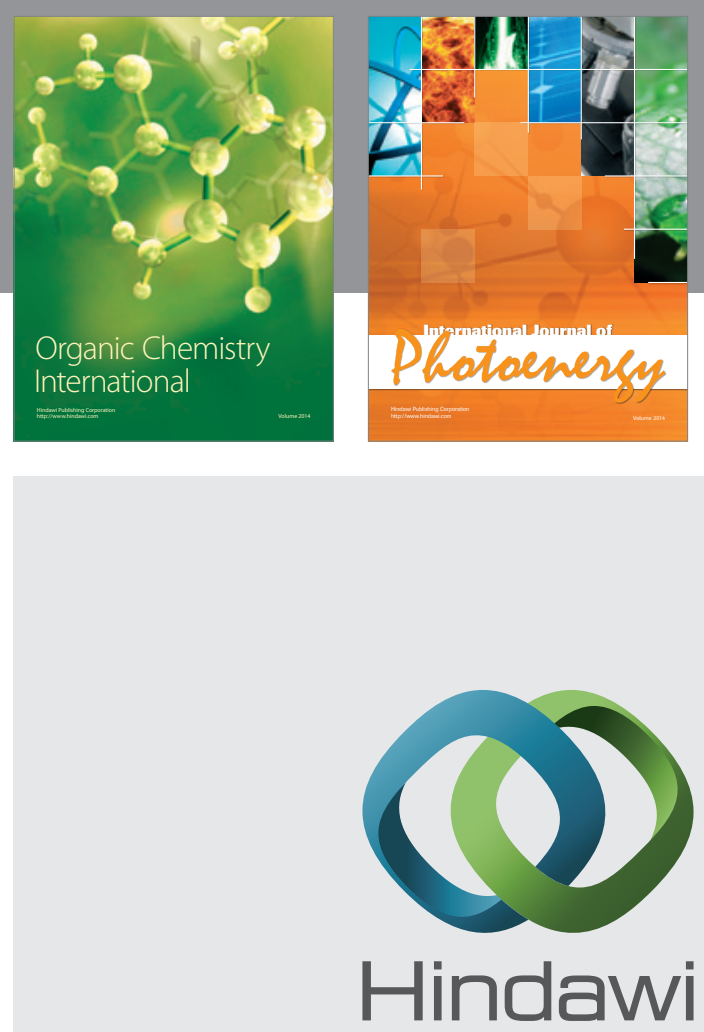

Submit your manuscripts at

http://www.hindawi.com

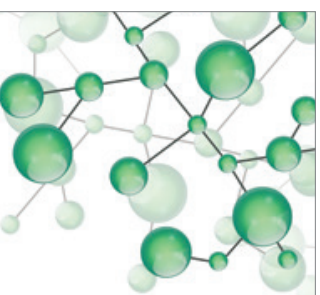

International Journal of

Inorganic Chemistry

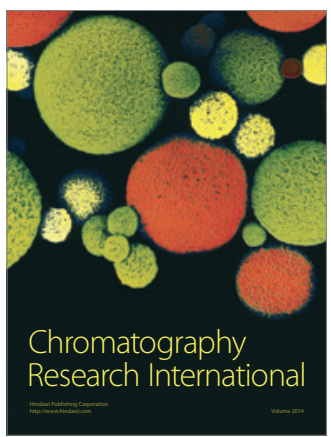

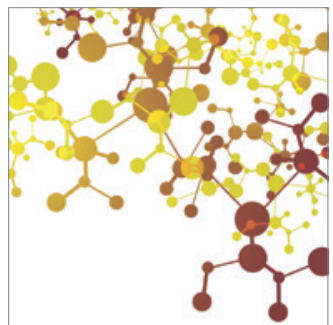

Applied Chemistry
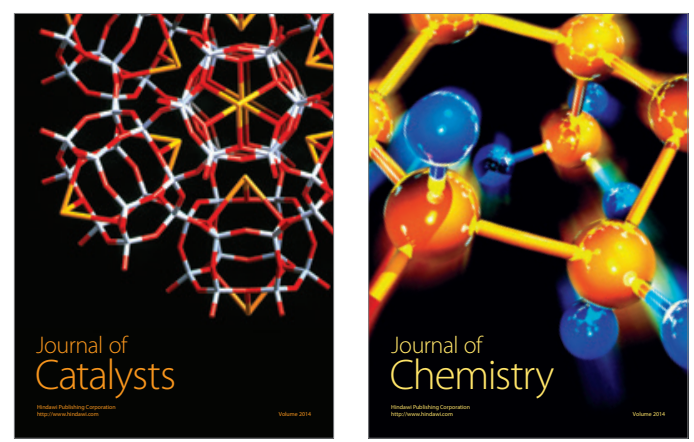
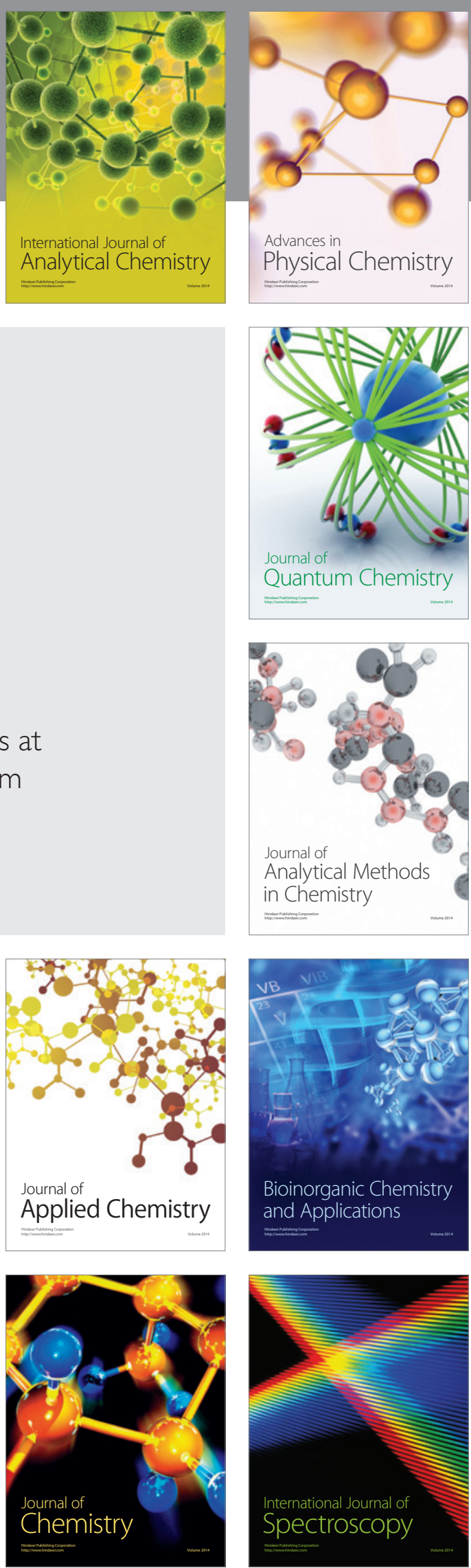